\title{
K 100. výročí narození prof. MUDr. Jiřího Šonky, DrSc.
}

\section{Štěpán Svačina, Martin Matoulek III. interní klinka 1. LF UK a VFN, Praha}

Prof. MUDr. Jiři Šonka, DrSc., byl jedním z nejvýznamnějších pracovníků III. interní kliniky 1. lékařské fakulty a jeden z nejvýznamnějších žáků prof. Josefa Charváta. Dnes je prof. Šonka považován především za zakladatele české obezitologie, jeho zaměření bylo však mnohem širši - jako jeden z mála byl skutečně opravdovým špičkovým odborníkem na endokrinologii, metabolická onemocnění i výživu současně.

Jiř́ Šonka se narodil 28. 12. 1920 v Praze. Studoval na francouzském reálném gymnáziu, které absolvoval v roce 1939. Za okupace pracoval nejprve v továrně na léčiva a pak tři roky v patologickém ústavu prof. Šikla a na interně u Alžbětinek. Lékařskou fakultu dokončil počátkem roku 1947 a po roce a půl praxe na chirurgickém a interním oddělení nemocnice v Mostě nastoupil 1. 7. 1948 na 3. interní kliniku prof. Charváta. Zde pracoval až do svého odchodu do důchodu 31. 12. 1999. Na starší fotografiích je profesor Šonka zobrazen jako klasický interní sekundární lékař. Později byl z politických důvodů přeřazen do laboratoře a na ambulanci. Prioritní je mnoho výsledků jeho vědecké práce v oblasti pentózového cyklu, dehydroepiandrosteronu, radiolobiologie a hormonálních regulací u obézních. Paralelně pracoval na ambulanci a vytvořil základy klinické obezitologie v České republice. Zemřel po dlouhé nemoci 9. 3. 2005. Obhájil kandidátskou (1958) i doktorskou (1964) dizertační práci na těchto tématech. Významně se zasloužil o prostorové úpravy III. interní kliniky do podoby, jak ji známe dnes. Ve složité době 50. let už se zdálo, že lidsky čistého a korektního asistenta Jiřího Šonku na nátlak vedení fakulty profesor Charvát již neudrží. Orientace na nemoc z ozáření a armádou podporovaný výzkum mu umožnila zůstat, ale nemohl učit studenty. Za výzkum významu pentózového cyklu pro patofyziologii a terapii nemoci z ozáření byl v roce 1967 vyznamenán státní cenou. Habilitován byl v roce 1966. Od vědecké práce $v$ problematice energetického metabolismu, zvláště otázek adaptace na snížený príjem potravy, se dostal až k velmi praktickým aplikacím - zavedl pobytové režimy pro obézní spojené s redukční dietou, nejprve v Třeboni, ve Zbirohu a pak dlouhá léta v Roudnici nad Labem. Navrhl nové, vědecky podložené režimy. A přestože napríklad od velmi proslulých hladovek se zcela upustilo, tak jím zavedené soustředění obézních pretrvávají dodnes. Publikoval mnoho publikací pro veřejnost o pohybu a dietách. Podílel se na indikaci prvních bariatrických výkonů u nás a je spojován i s počátky účinné farmakoterapie obezity u nás.

Vybudoval a vedl na klinice obezitologickou ambulanci a $v$ devadesátých letech podporoval osamostatnění České obezitologické společnosti, jejímž byl zvolen čestným předsedou. Do vysokého věku prakticky působil ve své ambulanci, kde jeho drobná, štíhlá až asketická postava působila v kontrastu s obézními pacienty někdy až komicky.

Z vědeckých publikací je nutno jmenovat především monografii „Pentózy" a pak řadu světově citovaných prací o dehydroepiandrostendionu, kterým se zabýval o dvě desetiletí dřive, než vrcholil výzkum tohoto hormonu v osmdesátých letech. V monografické anglické řadě časopisu Acta Universitatis Carolinae publikoval souhrnnou publikaci o dehydropeindrpsateronu a také monografii New trends in obesitology. Přes rozsáhlou vědeckou práci však nebyl před rokem 1989 navržen na jmenování profesorem; toto řízení proběhlo až počátkem 90. let.

Měl svůj suchý humor, se kterým zvládal i svoji početnou klientelu. Jeho páteční ambulance pro obézní se táhly do pozdního odpoledne a v letních měsících trávil týdny s obézními v Roudnici. Byl v problematice obezity neúnavným popularizátorem a dodnes je dobře znám generacím čtenářek ženských časopisů. Na památku pana profesora

Obr. 1. Prof. Šonka na počátku 80. let

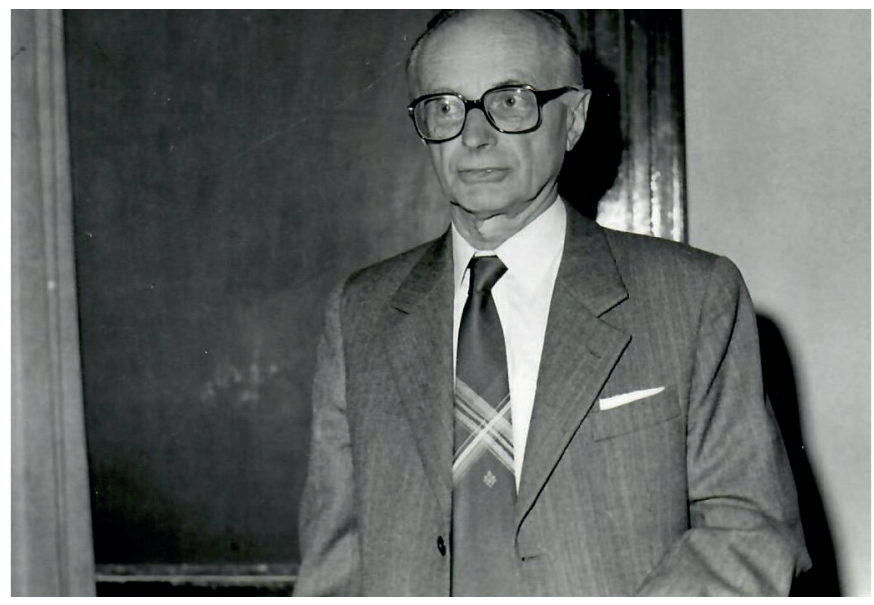


Obr. 2. Redukční pobyt pro obézní ve Zbirohu 60. léta - prof. Šonka vpravo

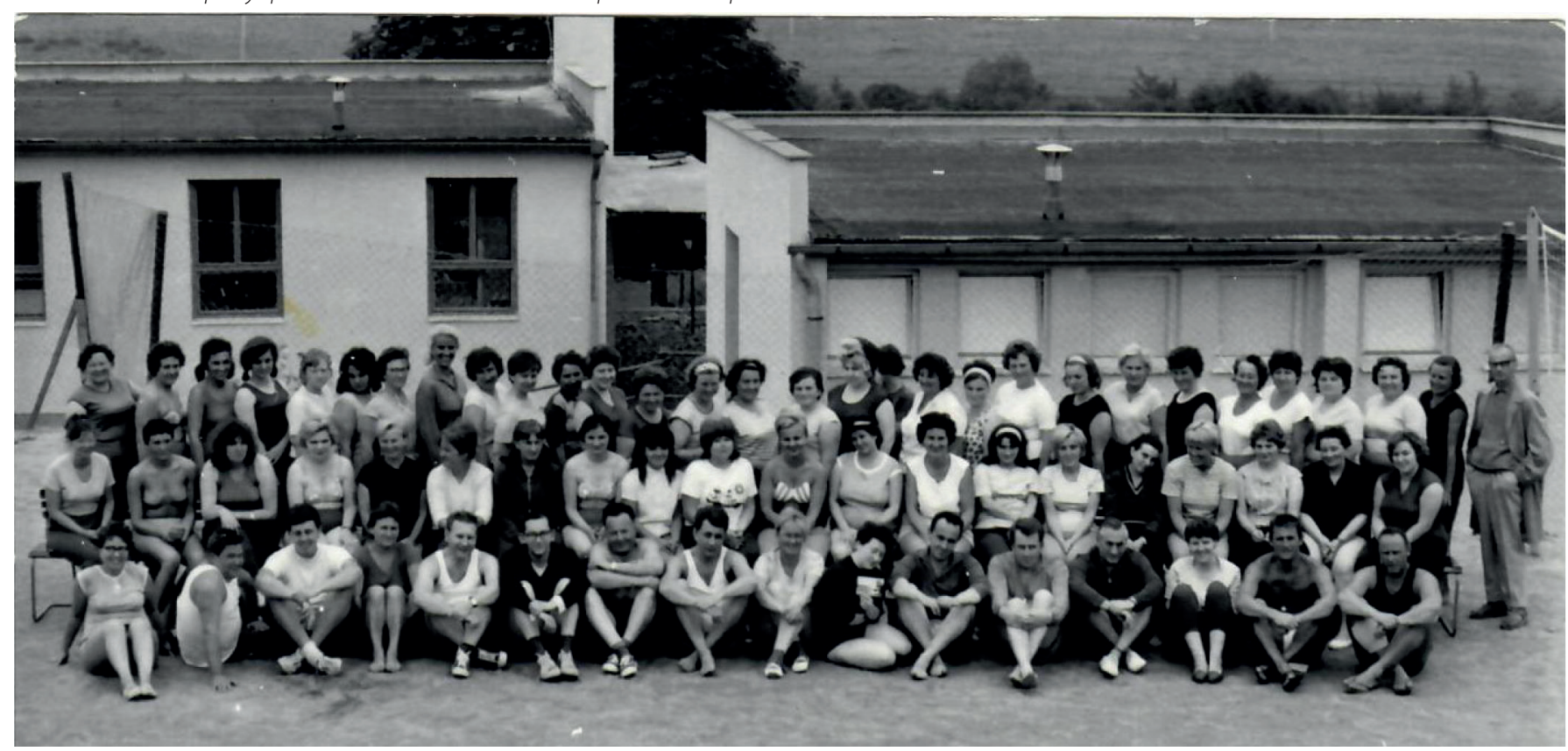

je vždy v lednu od roku 2006 pravidelně pořádán tzv. Šonkưv den věnovaný obezitě, jak z léčebného, tak z výzkumného hlediska. Prof. Jiři Šonka stejně jako profesor Charvát dokázal, že je možné pracovat špičkově výzkumně a současně praktickou klinickou prací prospět velkému počtu nemocných, a tak se na jeho práci se na 3. interní klinice daři navázat. V současné době je připravováno první XXL centrum, čímž obezitologická péče ve Všeobecné fakultní nemocnici dostane možnost komplexního rozvoje tak, jakji prof. Šonka před více než 50 lety zahájil. 